\title{
Effect of Al on Microstructure and Properties of Hot-Rolled 2205 Dual Stainless Steel
}

\author{
Qian Meng, ${ }^{1,2}$ Peiqing La, ${ }^{1}$ Liang Yao, ${ }^{1}$ Peng Zhang, ${ }^{1}$ Yupeng Wei, ${ }^{1}$ and Xin Guo ${ }^{1}$ \\ ${ }^{1}$ State Key Laboratory of Gansu Advanced Nonferrous Metal Materials, Lanzhou University of Technology, Lanzhou 730050, China \\ ${ }^{2}$ School of Mechatronic Engineering, Lanzhou Jiao Tong University, Lanzhou 730070, China
}

Correspondence should be addressed to Qian Meng; mymqmm@163.com and Peiqing La; pqla@lut.cn

Received 15 February 2016; Revised 18 May 2016; Accepted 7 June 2016

Academic Editor: Ming-Xing Zhang

Copyright (C) 2016 Qian Meng et al. This is an open access article distributed under the Creative Commons Attribution License, which permits unrestricted use, distribution, and reproduction in any medium, provided the original work is properly cited.

\begin{abstract}
The microstructure, mechanical properties, oxidation, and corrosion resistance of 2205 stainless steels without and with Al in a range of 0.5 to $2.5 \mathrm{wt}$.\% were investigated in this paper. The results showed that the matrix phase transformed from austenite to ferrite. The volume fraction of the ferrite in the steels decreased at first and then increased and was the lowest in the steel with $0.5 \mathrm{wt} . \% \mathrm{Al}$. Most of the $\mathrm{Al}$ was dissolved in the ferrite and austenite phases in the steels. The ultimate tensile strength and elongation rate of the steels increased at first and then decreased with the increasing Al content, with the highest values in the steel with 0.5 wt.\% $\mathrm{Al}$. The yield strength of the steels slightly increased from 544 to $607 \mathrm{MPa}$ due to the addition of Al. The oxidation rates of the steels with $\mathrm{Al}$ were much lower than that of the steel without $\mathrm{Al}$, and the rate of the steel with $1.5 \mathrm{wt} . \% \mathrm{Al}$ was the lowest, approximately 10 times lower than that of the steel without Al. The corrosion rates of the steels with 0.5 and $1.0 \mathrm{wt} . \% \mathrm{Al}$ were slightly higher than that of the alloy without Al. In general, the steel with $1 \mathrm{wt} . \% \mathrm{Al}$ had optimal properties.
\end{abstract}

\section{Introduction}

2205 stainless steel has received extensive attention due to its superior mechanical properties and good corrosion resistance in $\mathrm{Cl}^{-}$environments [1-4]. The $\mathrm{Cr}_{2} \mathrm{O}_{3}$ protective scale formed on the steel surface plays a key factor in determining the corrosion and oxidation resistance, but it is substantially damaged by water vapour due to the formation of volatile $\mathrm{Cr}$ oxyhydroxide species when the steel is exposed to a certain range of high temperature for a long time [5-7].

$\mathrm{Al}_{2} \mathrm{O}_{3}$ scale shows greater thermodynamic stability in oxygen than $\mathrm{Cr}_{2} \mathrm{O}_{3}$ and offers superior protection in many industrially relevant environments [8-10]. Yamamoto et al. reported that the $\mathrm{Al}_{2} \mathrm{O}_{3}$ scale can maintain good resistance to oxidation in air with $10 \%$ water vapour at 650 and $800^{\circ} \mathrm{C}$ for $\mathrm{Fe}-20 \mathrm{Ni}-14 \mathrm{Cr}-2.4 \mathrm{Al}$ steel [11]. A number of works over the past 40 years have created $\mathrm{Al}_{2} \mathrm{O}_{3}$-forming austenite stainless steels [12-16], but studies on $\mathrm{Al}_{2} \mathrm{O}_{3}$-forming 2205 stainless steel have not yet been reported. $\mathrm{Al}$ is a strong ferrite stabilizer, so the addition of $\mathrm{Al}$ to 2205 stainless steel may change the phase balance of austenite and ferrite, which may change the mechanical and corrosion resistance of the alloys.
A key need is the concurrent development of strength and corrosion resistance.

In our previous works, 316L and 310S steels with different $\mathrm{Al}$ contents were fabricated by vacuum induction melting, and good corrosion and oxidation resistance were obtained with no loss of strength [17-20].

In this paper, the effects of the $\mathrm{Al}$ content on the microstructure, mechanical properties, corrosion, and oxidation resistance of 2205 stainless steel were investigated to develop a new microstructure- and property-tailoring method and develop a new 2205-based steel with improved properties.

\section{Experimental Procedure}

2205 stainless steels without $\mathrm{Al}$ and with $\mathrm{Al}(0.5,1,1.5,2$, and 2.5 wt.\%) were used as experimental alloys. Powders of the alloying elements were weighted and dry-mixed in a ballmixing mill with $\mathrm{Al}_{2} \mathrm{O}_{3}$ spheres at a speed of $150 \mathrm{rpm}$ for 8 hours. The mixed powders were pressed and compacted in a steel mould and then melted by arc-melting in a vacuum arc-melting furnace and casted as ingots. To obtain a uniform 
TABLE 1: Chemical compositions of the steels (wt.\%).

\begin{tabular}{lccccccccc}
\hline Alloys & $\mathrm{Al}$ & $\mathrm{Cr}$ & $\mathrm{Ni}$ & $\mathrm{Mn}$ & $\mathrm{Si}$ & $\mathrm{Mo}$ & $\mathrm{N}$ & $\mathrm{C}$ & $\mathrm{Fe}$ \\
\hline 1\# (2205) & 0 & 20.5 & 5.65 & 0.88 & 0.26 & 3.15 & 0.25 & 0.03 & $\mathrm{Bal}$ \\
2\# & 0.36 & 20.8 & 5.81 & 0.71 & 0.35 & 3.22 & 0.28 & 0.03 & $\mathrm{Bal}$ \\
3\# & 0.90 & 20.6 & 5.59 & 0.72 & 0.36 & 3.20 & 0.22 & 0.04 & $\mathrm{Bal}$ \\
4\# & 1.41 & 20.8 & 5.39 & 0.68 & 0.49 & 3.17 & 0.15 & 0.03 & $\mathrm{Bal}$ \\
5\# & 1.79 & 21.8 & 5.70 & 0.85 & 0.47 & 3.50 & 0.14 & 0.04 & $\mathrm{Bal}$ \\
6\# & 2.31 & 20.33 & 5.91 & 0.75 & 0.46 & 3.20 & 0.14 & 0.03 & $\mathrm{Bal}$ \\
\hline
\end{tabular}

microstructure, the ingots were melted 3-4 times. The actual chemical compositions of the alloys with different Al contents were analysed by an X-ray fluorescence spectrometer, as shown in Table 1.

The 2205 stainless steels with different $\mathrm{Al}$ content ingots were heated at $1150^{\circ} \mathrm{C}$ for $30-40 \mathrm{~min}$ and then pressed as plates under $20 \mathrm{MPa}$ pressure with a thickness reduction of $55-58 \%$. Then, the steels were heated to $1170-1200^{\circ} \mathrm{C}$ for $20-$ $30 \mathrm{~min}$ and hot-rolled as plates with a thickness of $3 \mathrm{~mm}$ by handle-rolling equipment to obtain a thickness reduction of 30-40\%. The hot-rolled 2205 stainless steels with different $\mathrm{Al}$ contents were homogenized at $1090^{\circ} \mathrm{C}$ for 30 minutes and then water-quenched to room temperature.

The hot-rolled specimens were polished with 2000-grit emery papers, mechanically polished and etched in a solution of $\mathrm{FeCl}_{3}+30 \mathrm{HCl}+100 \mathrm{H}_{2} \mathrm{O}$. The phase and microstructures of the as-casted and solution-treated specimens were examined by optical microscopy, scanning electron microscopy (SEM; model JSM-6700F, JEOL, Japan) attached to energy dispersive spectroscopy (EDS) and D8, and advance X-ray diffraction using $\mathrm{Cu} \mathrm{K} \alpha$ radiation. Some related SEM images were quantitatively examined by Ipwin 6 software, and the amount of ferrite phase relative to the whole was taken as its volume fraction.

Tensile specimens with a thickness of $1.2 \mathrm{~mm}$, length of $10 \mathrm{~mm}$, and width of $2.2 \mathrm{~mm}$ were cut from steel plates by a line-cutting machine and polished using 600-grit SiC paper. Tensile tests were carried out at room temperature using a universal material mechanical properties tester with a tension speed of $0.2 \mathrm{~mm} / \mathrm{min}$ and repeated three times to ensure obtaining a reasonably representative value of each mechanical property. The elongation was measured and calculated using the Chinese GB/T 228-2002 standard method. Three specimens of each steel were tested, and average values of the yield strength, tensile strength, and elongation rate were obtained. The data deviation was less than $10 \%$.

Specimens with dimensions of $15 \mathrm{~mm} \times 10 \mathrm{~mm} \times 3 \mathrm{~mm}$ were cut from the steel plates and polished using 1000-grit $\mathrm{SiC}$ paper. The specimens were exposed at $1000^{\circ} \mathrm{C}$ in air for $100 \mathrm{~h}$ in a heat-resisting furnace. The mass loss of the specimens before and after the exposure was measured by an electronic balance with a precision of $0.1 \mathrm{mg}$ according to the Chinese GB/T 13303-1991 standard method. Three specimens of each type of steel were tested, and average values were obtained. The data deviation was less than $10 \%$.

Steel specimens with dimensions of $15 \mathrm{~mm} \times 10 \mathrm{~mm}$ $\times 3 \mathrm{~mm}$ were cut and polished using 1000-grit SiC paper.

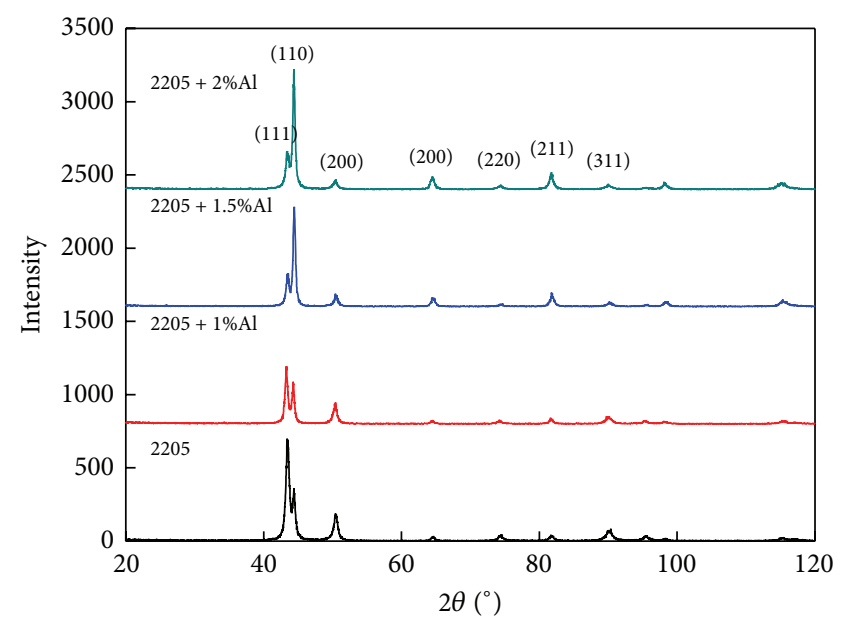

FIGURE 1: XRD patterns of steels without and with Al.

TABLE 2: Volume fractions of ferrite and austenite in the steels (vol.\%).

\begin{tabular}{lcccccc}
\hline Steels & 0 & 0.5 & 1.0 & 1.5 & 2.0 & 2.5 \\
\hline Ferrite & 35 & 20 & 46 & 71 & 77 & 86 \\
Austenite & 65 & 80 & 54 & 29 & 23 & 14 \\
\hline
\end{tabular}

Corrosion resistance tests were carried out in a $5 \% \mathrm{H}_{2} \mathrm{SO}_{4}$ solution for $8 \mathrm{~h}$, and then the specimens were cleaned by an ultrasonic cleaner in distilled water. The mass loss of the specimens before and after the corrosion was measured by an electronic balance with a precision of $0.1 \mathrm{mg}$ using the Chinese GB/T 4334.6-2000 standard method. Three specimens of each type of steel were tested, and average values were obtained. The data deviation was less than $10 \%$.

\section{Results}

Figure 1 shows X-ray diffraction patterns of the alloys without and with 1.0, 1.5, and $2.0 \mathrm{wt} . \% \mathrm{Al}$. It can be found that the alloys are composed of ferrite and austenite phases. The peak intensity of the ferrite phase increases with the increasing $\mathrm{Al}$ content. Other Al-rich phases were not observed by XRD.

Figure 2 illustrates the optical microstructures of the alloys with different $\mathrm{Al}$ contents. It can be found that the microstructures consist of a dark ferrite phase and a bright austenite phase. The volume fraction of the ferrite of the alloy with 0.5 wt. $\% \mathrm{Al}$ is slightly lower than that of the alloy without $\mathrm{Al}$. When the $\mathrm{Al}$ content of the alloys is more than $0.5 \mathrm{wt} . \%$, the volume fraction of the ferrite gradually increases in the alloys (Table 2). The islands of ferrite phase are uniformly distributed in the austenite matrix when the $\mathrm{Al}$ content of the alloys is less than $1.5 \mathrm{wt}$.\% while the ferrite grain size is in the range of $10-100 \mu \mathrm{m}$. The shape of the austenite phase transformed from the matrix to islands with the increasing of the $\mathrm{Al}$ content from 1.5 to $2.5 \mathrm{wt} . \%$, leading it to be uniformly distributed in the ferrite matrix. The average grain size of the austenite is in the range of $10-20 \mu \mathrm{m}$. The ferrite volume fractions in the alloys with different Al contents were 


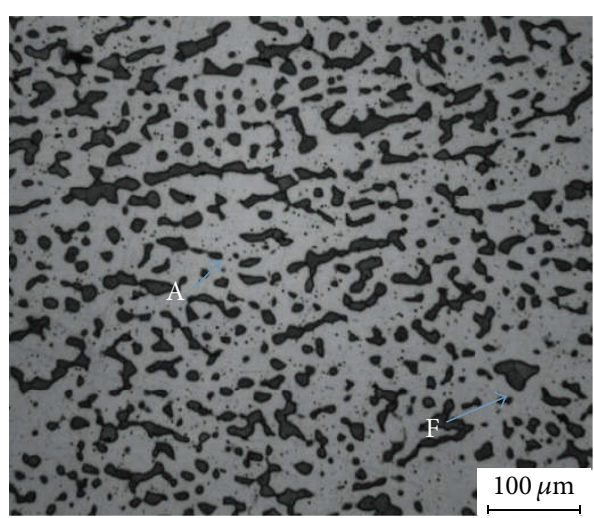

(a)

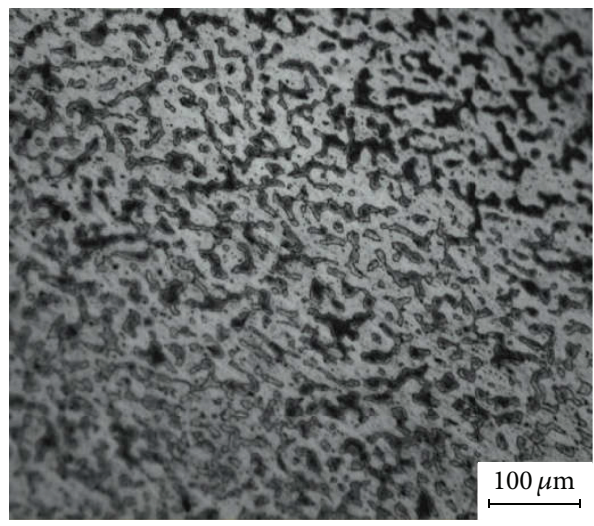

(c)

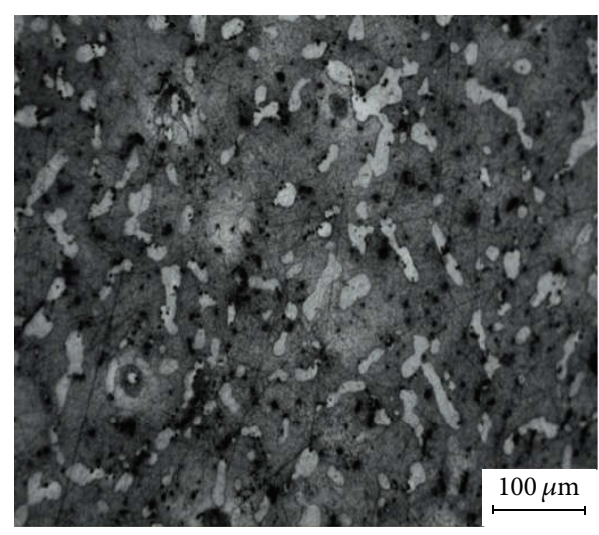

(e)

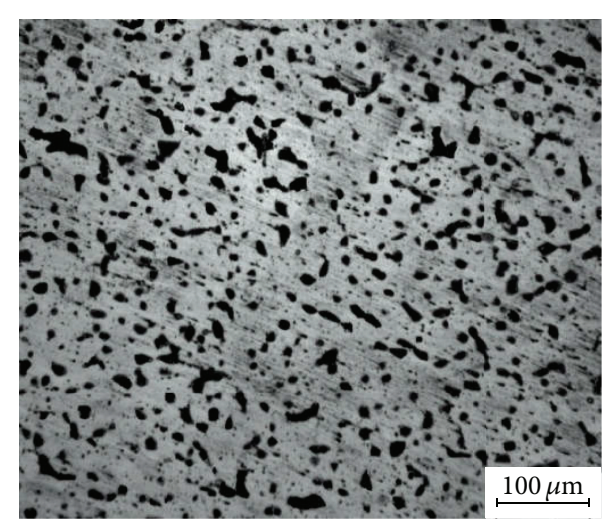

(b)

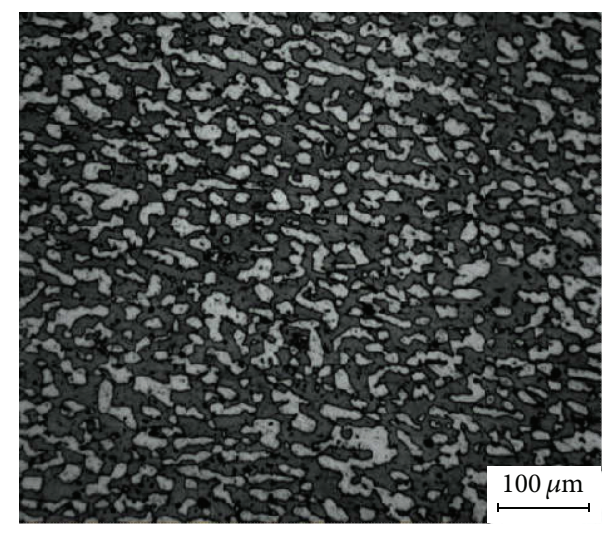

(d)

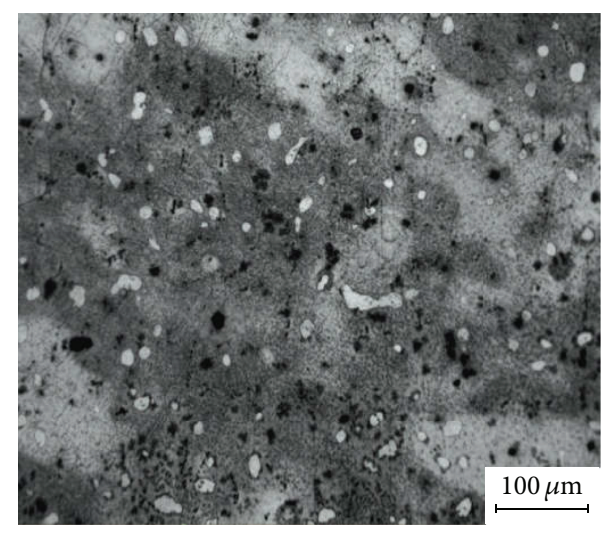

(f)

Figure 2: Optical microstructures of steels without $\mathrm{Al}$ (a) and with 0.5 (b), 1.0 (c), 1.5 (d), 2.0 (e), and 2.5 wt.\% $\mathrm{Al}$ (f).

calculated to be approximately $0.35,0.2,0.46,0.71,0.77$, and 0.86 , respectively.

Figure 3 shows the distributions of the alloying elements in the alloys with 0.5 and $1.5 \mathrm{wt} \% \mathrm{Al}$, where most of $\mathrm{Al}$ is uniformly distributed in the ferrite and austenite phases. However, a few tiny black inclusions composed of $\mathrm{Mn}$ and $\mathrm{Al}$ exist in the alloy with $1.5 \mathrm{wt} . \% \mathrm{Al}$. Figure 4 shows tensile stress-strain curves of the alloys with different $\mathrm{Al}$ contents. The yield and ultimate tensile strength obtained from the curves and elongation rates of the alloys are shown in Figure 5. The ultimate tensile strength and elongation rate of the alloys increase at first and then decrease with the increasing $\mathrm{Al}$ content. The alloy with $0.5 \mathrm{wt} . \% \mathrm{Al}$ has the highest ultimate tensile strength of $780 \mathrm{MPa}$ and an elongation rate of $55 \%$. The ultimate tensile strength and elongation rate of the alloys without $\mathrm{Al}$ and with $1.0 \mathrm{wt} . \%$ $\mathrm{Al}$ are almost the same, and the yield strength of the alloys with $\mathrm{Al}$ contents in the range of 0.5 to $2.0 \mathrm{wt} . \%$ also does not significantly change. The alloy with $2.5 \mathrm{wt} . \% \mathrm{Al}$ has the highest yield strength $(607 \mathrm{MPa})$ but the lower ultimate strength, which must be related to a low work hardening capacity of this alloy. 

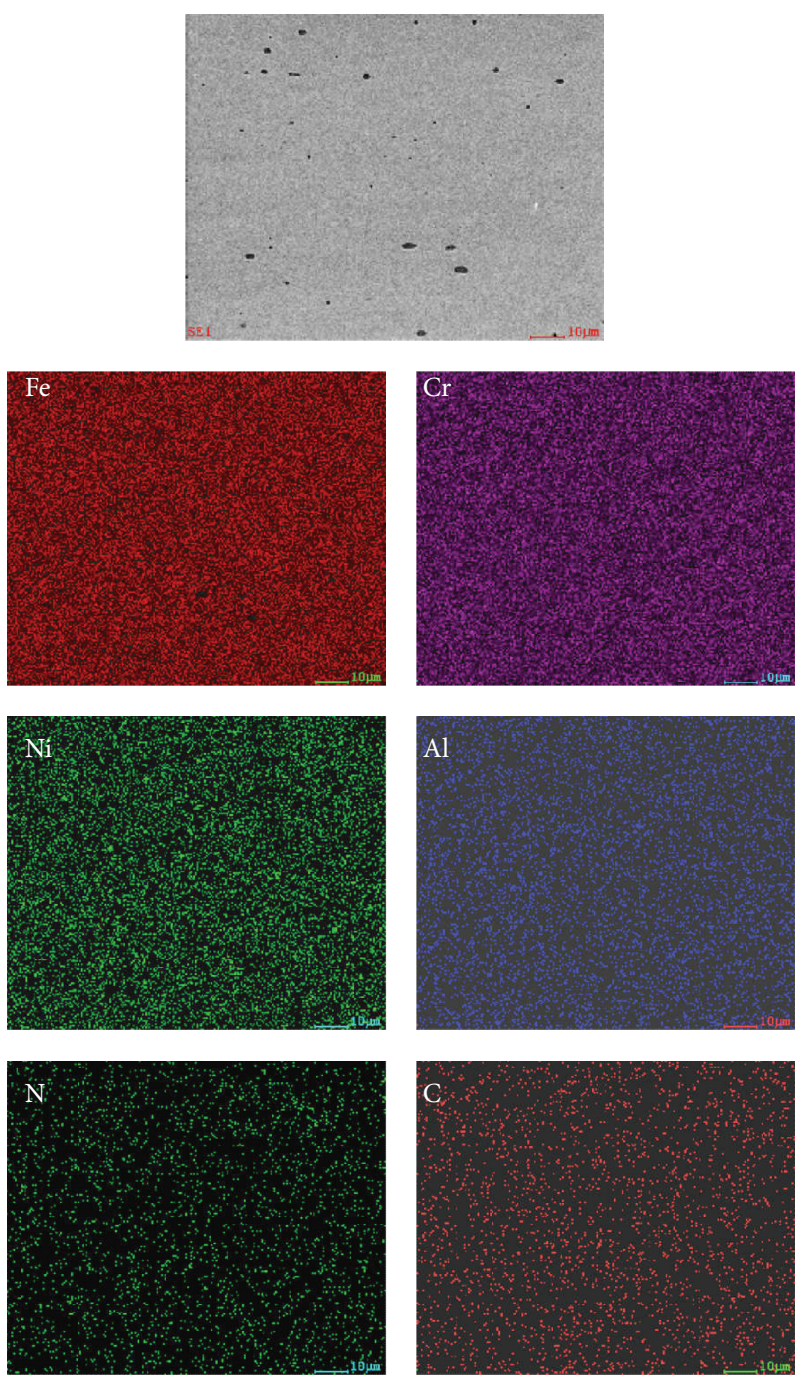

(a)
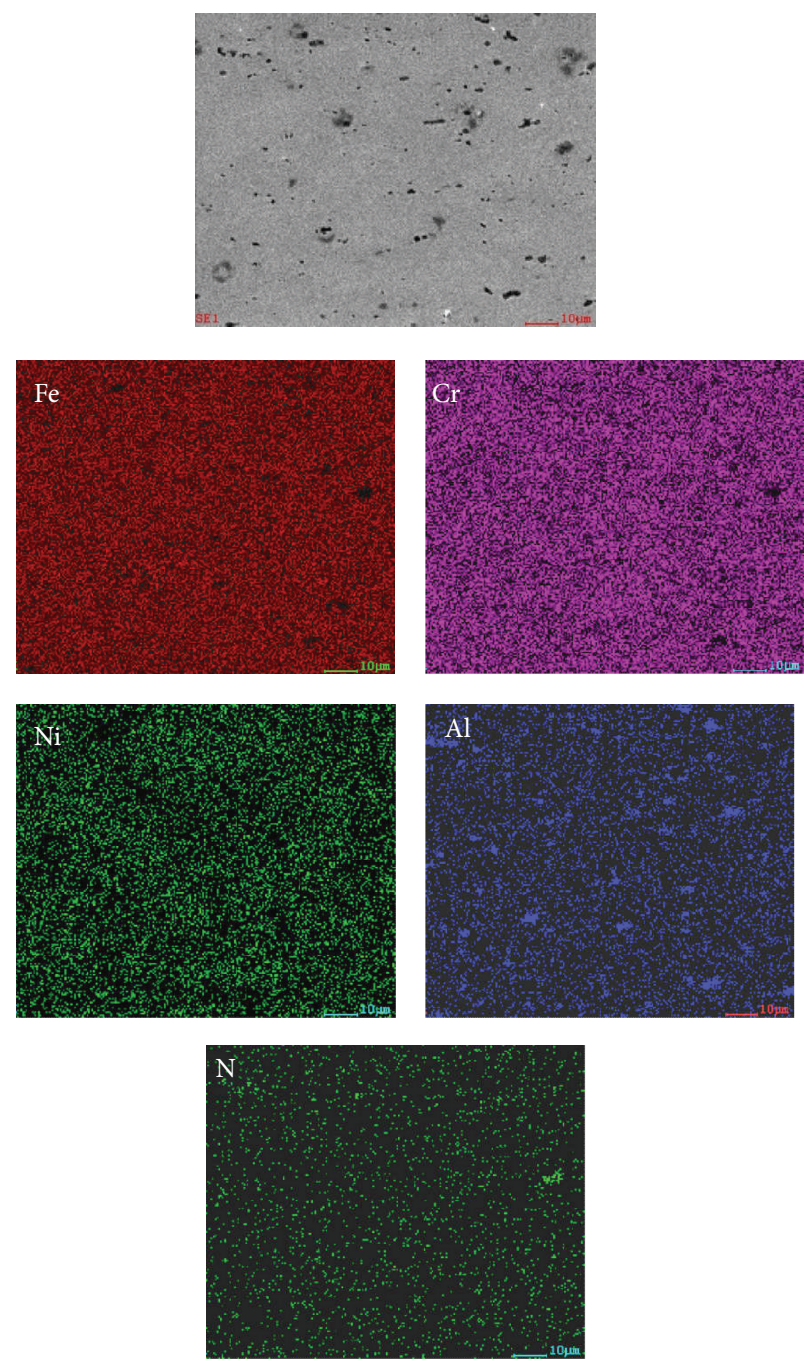

(b)

FIgURE 3: EDS elemental distribution of the steels with (a) 0.5 and (b) $1.5 \mathrm{wt} . \% \mathrm{Al}$.

Figure 6 shows oxidizing kinetics curves and the oxidation rates of the alloys with different $\mathrm{Al}$ contents as function of exposure time. The oxidation rates of the alloys dramatically decrease with the increasing $\mathrm{Al}$ content, reaching a minimum value at $1.5 \mathrm{wt} . \% \mathrm{Al}$ and then slowly increasing. The oxidation rate of the alloy with $0.5 \mathrm{wt} . \% \mathrm{Al}$ is slightly lower than that of the alloy without Al. The oxidation rate of the alloy with $1.5 \mathrm{wt} . \% \mathrm{Al}$ is $0.3401 \mathrm{~g} / \mathrm{m}^{2} \cdot \mathrm{h}$, approximately 10 times lower than that of the alloy without Al.

Figure 7 shows the oxidation surfaces of the alloys. Those of the alloys with 1.0 and $1.5 \mathrm{wt} . \% \mathrm{Al}$ are covered by a uniform and dense oxide scale, whereas cracks and pores appear on the surface of the alloy with $0.5 \mathrm{wt} . \% \mathrm{Al}$. This result is consistent with the change in the oxidation resistance of the alloys. Figure 8 shows that the corrosion rates of the alloys with 0.5 and $1.0 \mathrm{wt} . \% \mathrm{Al}$ are slightly higher than that of the alloy without $\mathrm{Al}$. On the other hand, the corrosion rates of the alloys with 1.5, 2.0, and $2.5 \mathrm{wt} . \% \mathrm{Al}$ are much higher than the others.

\section{Discussion}

Because the solid solution limits of $\mathrm{Al}$ in the bcc ferrite and $\mathrm{fcc}$ austenite phases are higher than $10 \mathrm{wt} . \%$ according to Fe$\mathrm{Cr}-\mathrm{Ni}-\mathrm{Al}$ phase diagram, the $\mathrm{Al}$ in the steels with different contents of $\mathrm{Al}$ was dissolved in the ferrite and austenite, and no Al-rich phase was observed [21]. $\mathrm{Al}$ is a strong ferrite stabilizer, so the volume fraction of the ferrite in the alloys could gradually increase with the increasing $\mathrm{Al}$ content, although that of the alloy with $0.5 \mathrm{wt} . \% \mathrm{Al}$ was less than that of the alloy without Al. This can be explained by the fact that the bonding energy of $\mathrm{Al}-\mathrm{N}$ is higher than that of $\mathrm{Fe}$ $\mathrm{N}$, which causes the diffusion coefficient of $\mathrm{N}$ in the $\mathrm{Fe}$ to decrease due to the addition of $\mathrm{Al}$ and the solid solubility of $\mathrm{N}$ in the matrix to increase because the escape of $\mathrm{N}$ from the matrix was hampered [22]. $\mathrm{N}$ is a strong austenite stabilizer. The increased solid solubility of $\mathrm{N}$ in the matrix contributed to the increase of the austenite volume fraction in the alloy with $0.5 \mathrm{wt} . \% \mathrm{Al}$. With the increasing of the $\mathrm{Al}$ content from 1 


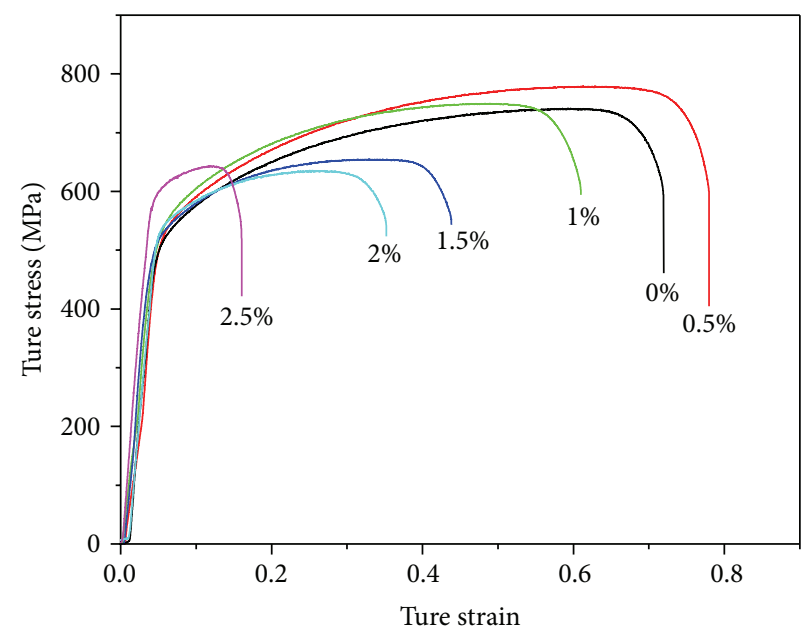

FIGURE 4: Stress-strain curves of the steels.

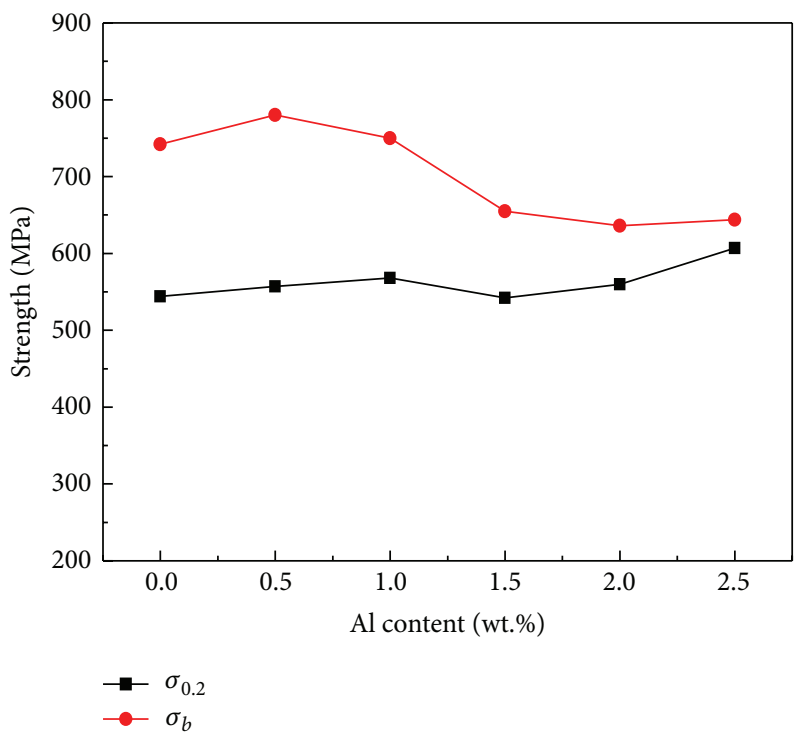

(a)

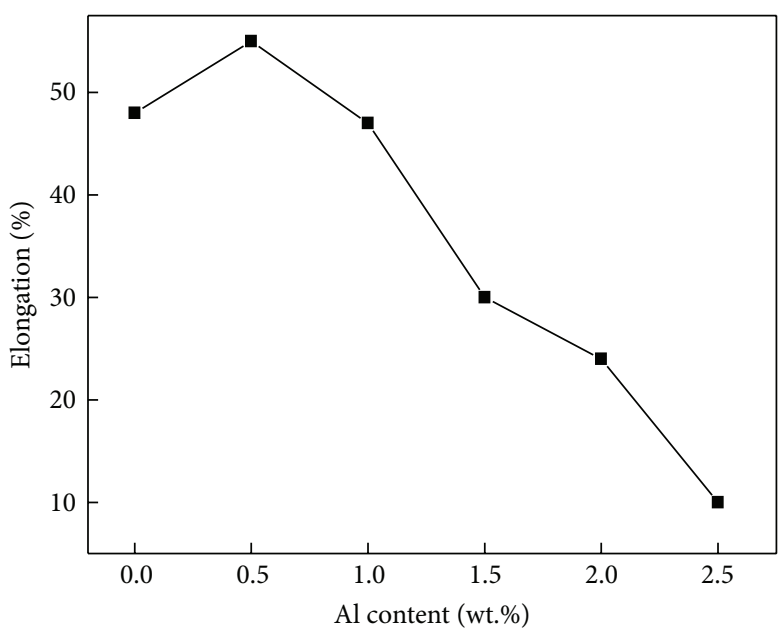

(b)

FIGURE 5: Yield and tensile strength (a) and elongation rate of the steels (b).

to $2.5 \mathrm{wt} . \%$, the solid solubility of $\mathrm{Al}$ in the matrix improved, which accelerated the formation of the ferrite phase.

The yield strength of the alloys gradually increased when the $\mathrm{Al}$ content is more than $1.5 \mathrm{wt} . \%$, which can be attributed to the solid solution strengthening effect of Al element [23]. However, there exists a clear relationship between the YS and ferrite volume fraction in the alloys with $\mathrm{Al}$, with the YS increasing gradually with the $\mathrm{Al}$ content. The ferrite phase is regarded as stronger than the austenite phase, which causes the addition of Al to enhance the YS of the alloys [24].

The ultimate tensile strengths and elongation rates of the alloys with different $\mathrm{Al}$ contents increased at first and then decreased. The alloy with $0.5 \mathrm{wt} \% \mathrm{Al}$ has higher values than that without $\mathrm{Al}$, which is attributed to the increasing volume fraction of the austenite phase. It was reported that strain hardening has a much greater influence on the UTS than the chemical composition [25], and strain hardening is related to the dislocation strengthening mechanism [26].

The SFE of the austenite phase is reduced due to the solid solution containing more $\mathrm{N}$ in the austenite, which contributes to planar slip and enhances the ultimate tensile strength [27]. When the Al content of the alloy is more than $1 \mathrm{wt} . \%$, the ultimate tensile strength and elongation rate of the alloys are significantly reduced compared to those of the alloy without Al. The reason for this phenomenon is that the ultimate tensile strength of the austenite phase is higher than that of the ferrite phase, which lowers the ultimate tensile strength of the high-Al alloys.

The oxide scale on the alloy surface plays a key role in the oxidation resistance [28]. With the increasing $\mathrm{Al}$ content, the $\mathrm{Cr}_{2} \mathrm{O}_{3}$ scale on the alloy surface gradually decreases and the $\mathrm{Al}_{2} \mathrm{O}_{3}$ increases. It is well known that the thermodynamic 


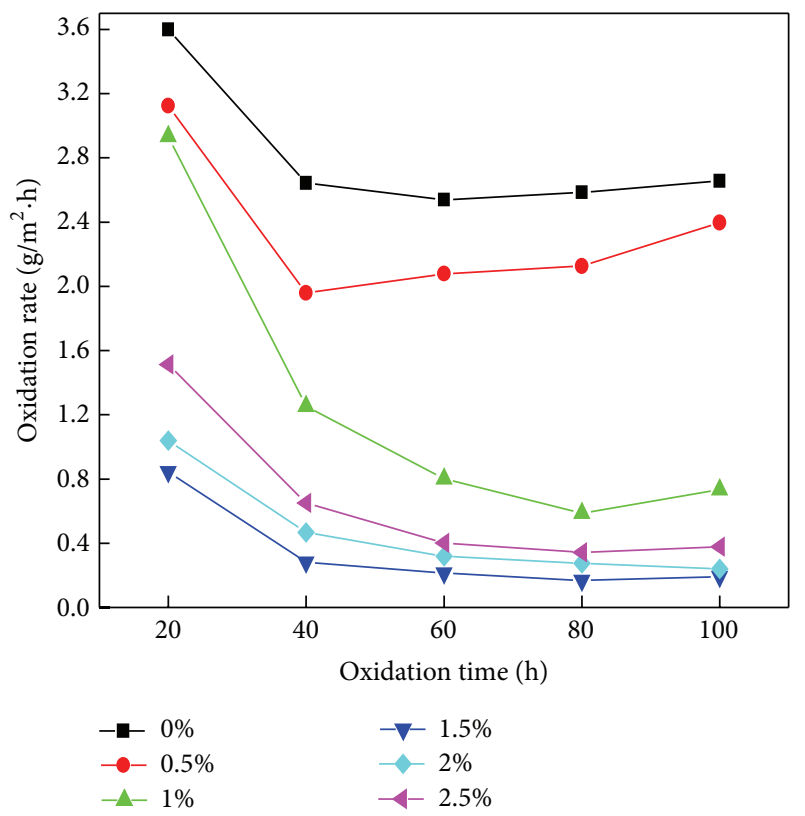

(a)

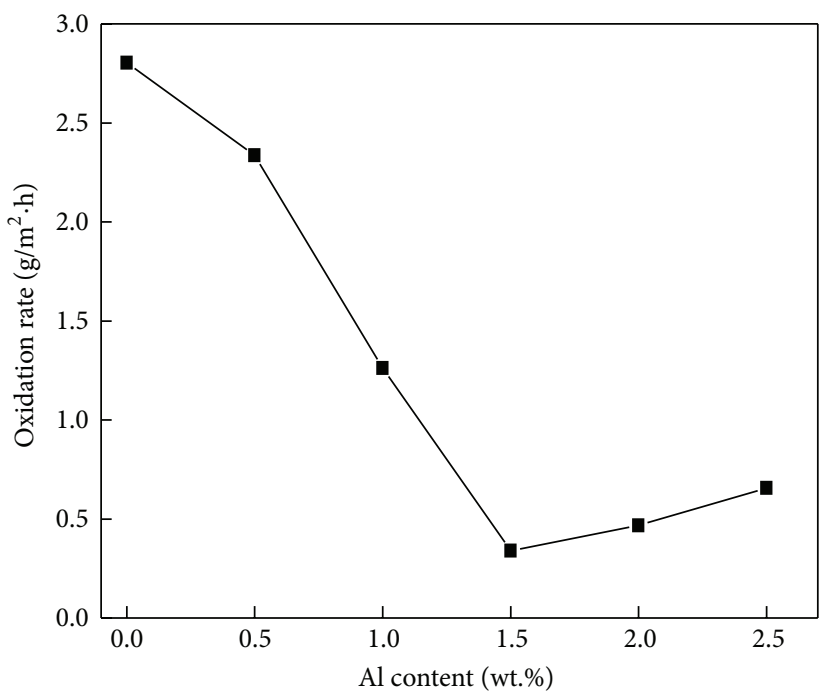

(b)

FIgure 6: Alloys with different $\mathrm{Al}$ contents exposed at $1000^{\circ} \mathrm{C}$ in air for $100 \mathrm{~h}$. (a) Oxidation kinetics curves and (b) oxidation rate.

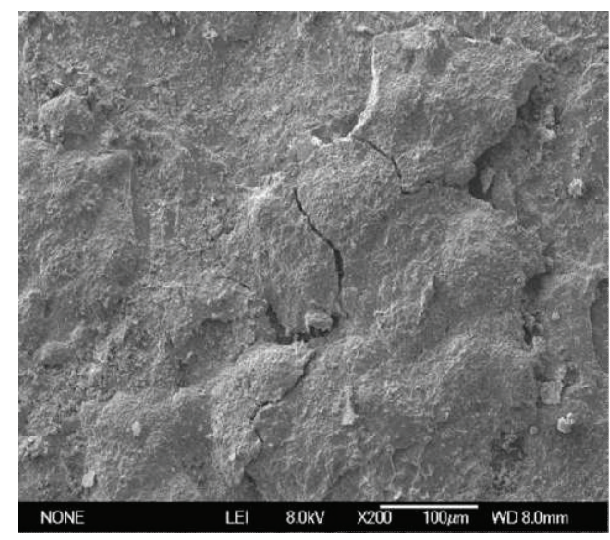

(a)

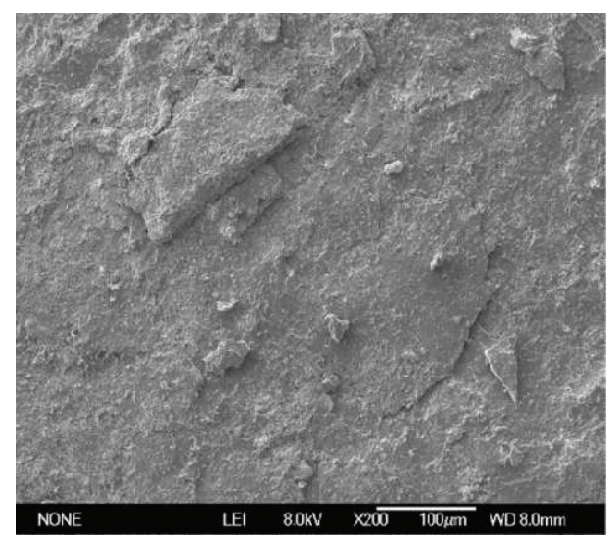

(b)

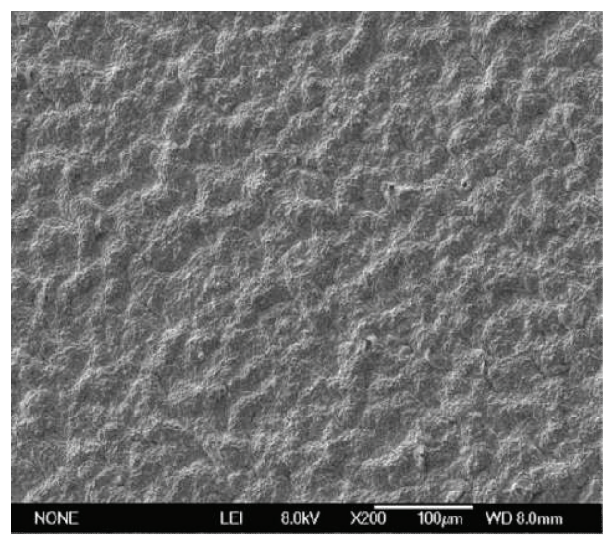

(c)

FIGURE 7: Oxidation surface morphologies of the steels with (a) 0.5 , (b) 1.0, and (c) 1.5 wt.\% Al. 


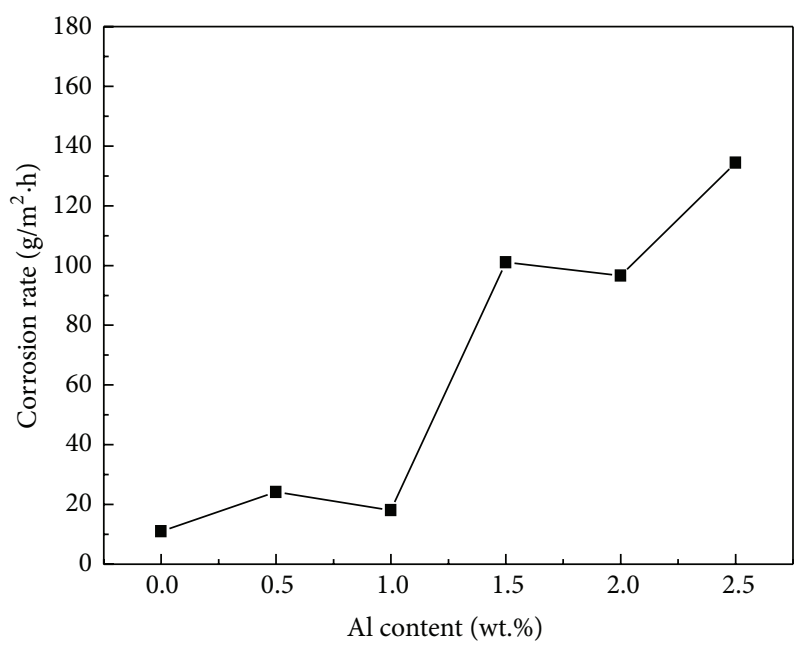

FIGURE 8: Corrosion resistance of the steels with different $\mathrm{Al}$ contents.

stability of the $\mathrm{Al}_{2} \mathrm{O}_{3}$ scale is superior to that of the $\mathrm{Cr}_{2} \mathrm{O}_{3}$ scale [29]. Hence, the oxidation rate of the alloys gradually decreases with the increasing $\mathrm{Al}$ content up to $1.5 \%$. The lowest oxidation rate of the alloy with $1.5 \mathrm{wt} . \% \mathrm{Al}$ is due to its best oxidation surface morphologies, as shown in Figure 7(c). The oxidation rates of the alloys with 2 and $2.5 \mathrm{wt} . \% \mathrm{Al}$ are slightly increased, which may be related to the diffusion rates of the alloying elements.

The passive film plays a significant role in the corrosion of 2205 in acid reducing media. The passive film can prevent metal ions from diffusing. However, the presence of $\mathrm{Al}$ can lead to metal ion dissolution and the increase of corrosion rate may be consequence of this. Thus, the steels with 0.5 or $1.0 \mathrm{wt} . \% \mathrm{Al}$ exhibited higher corrosion rates than the steel without $\mathrm{Al}$. In the steels with $1.5,2.0$, and $2.5 \mathrm{wt} . \% \mathrm{Al}$, the dramatic increase in the corrosion rate can be attributed to the increased ferrite to austenite phase ratio, which would lead to galvanic action in acid reducing media [30].

\section{Conclusions}

(1) The ferrite volume fraction in the alloy with $0.5 \mathrm{wt} . \%$ $\mathrm{Al}$ is slightly lower than that of the alloy without $\mathrm{Al}$, but it gradually increases with the $\mathrm{Al}$ content in the range of 0.5 to $2.5 \mathrm{wt} . \%$, and the morphology of the ferrite transforms from islands to a continuous matrix. Most of $\mathrm{Al}$ in the steels was dissolved in the ferrite and austenite phases.

(2) The ultimate tensile strength and elongation of the alloy with $0.5 \mathrm{wt} . \% \mathrm{Al}$ are higher than those in the alloy without $\mathrm{Al}$, but they decreased as the $\mathrm{Al}$ increases from 0.5 to $2.5 \mathrm{wt}$. $\%$.

(3) The alloys with Al have much better oxidation resistance than those without $\mathrm{Al}$ owing to the formation of $\mathrm{Al}_{2} \mathrm{O}_{3}$ oxidation scale on the alloy surface. The alloy with $1.5 \mathrm{wt} . \% \mathrm{Al}$ had the best oxidation resistance, approximately 10 times lower than that of the alloy without $\mathrm{Al}$. The corrosion rates of the steels with 0.5 to $1.0 \mathrm{wt} . \% \mathrm{Al}$ were slightly lower than that of the alloy without $\mathrm{Al}$, but those of the other alloys were much higher.

\section{Competing Interests}

The authors declare that they have no competing interests.

\section{Acknowledgments}

The work is supported by the Natural Science Foundation of China (51561020), the Youth Science Foundation of Lan Zhou Jiao Tong University (2012016), and the Natural Science Foundation of Gansu (214176).

\section{References}

[1] T. H. Chen and J. R. Yang, "Microstructural characterization of simulated heat affected zone in a nitrogen-containing 2205 duplex stainless steel," Materials Science and Engineering A, vol. 338, no. 1-2, pp. 166-181, 2002.

[2] V. Muthupandi, P. B. Srinivasan, S. K. Seshadri, and S. Sundaresan, "Effect of weld metal chemistry and heat input on the structure and properties of duplex stainless steel welds," Materials Science and Engineering A, vol. 358, no. 1-2, pp. 9-16, 2003.

[3] D. E. Nelson, W. A. Baeslack III, and J. C. Lippold, "Characterization of the weld structure in a duplex stainless steel using color metallography," Metallography, vol. 18, no. 3, pp. 215-225, 1985.

[4] H. Chunyong and L. Weiwei, 2205 Double-Phase Stainless Steel, Shanxi Science and Technology Press, Xi'an, China, 2006.

[5] P. Kofstad, High Temperature Corrosion, Elsevier, London, UK, 1988.

[6] E. J. Opila, "Volatility of common protective oxides in hightemperature water vapor: current understanding and unanswered questions," Materials Science Forum, vol. 765, pp. 461464, 2004.

[7] B. A. Pint, R. Peraldi, and P. J. Maziasz, "The use of model alloys to develop corrosion-resistant stainless steels," Materials Science Forum, vol. 461-464, pp. 815-822, 2004.

[8] V. Ramakrishnan, J. A. McGurty, and N. Jayaraman, "Oxidation of high-aluminum austenitic stainless steels," Oxidation of Metals, vol. 30, no. 3, pp. 185-200, 1988.

[9] J. C. Pivin, D. Delaunay, C. Roques-Carmes, A. M. Huntz, and P. Lacombe, "Oxidation mechanism of Fe-Ni-20-25Cr-5Al alloysinfluence of small amounts of yttrium on oxidation kinetics and oxide adherence," Corrosion Science, vol. 20, no. 3, pp. 351-373, 1980.

[10] P. Jussila, K. Lahtonen, M. Lampimäki, M. Hirsimäki, and M. Valden, "Influence of minor alloying elements on the initial stages of oxidation of austenitic stainless steel materials," Surface and Interface Analysis, vol. 40, no. 8, pp. 1149-1156, 2008.

[11] Y. Yamamoto, M. P. Brady, Z. P. Lu et al., "Creep-resistant, $\mathrm{Al}_{2} \mathrm{O}_{3}$-forming austenitic stainless steels," Science, vol. 316, no. 5823, pp. 433-436, 2007.

[12] Z. K. Teng, C. T. Liu, G. Ghosh, P. K. Liaw, and M. E. Fine, "Effects of $\mathrm{Al}$ on the microstructure and ductility of NiAlstrengthened ferritic steels at room temperature," Intermetallics, vol. 18, no. 8, pp. 1437-1443, 2010.

[13] K. Kondo, Y. Miwa, N. Okubo, Y. Kaji, and T. Tsukada, "Development of corrosion-resistant improved Al-doped austenitic 
stainless steel," Journal of Nuclear Materials, vol. 417, no. 1-3, pp. 892-895, 2011.

[14] M. P. Brady, Y. Yamamoto, M. L. Santella et al., "The development of alumina-forming austenitic stainless steels for hightemperature structural use," JOM, vol. 60, no. 7, pp. 12-18, 2008.

[15] V. Ramakrishnan, J. A. McGurty, and N. Jayaraman, "Oxidation of high-aluminum austenitic stainless steels," Oxidation of Metals, vol. 30, no. 3-4, pp. 185-200, 1988.

[16] D. V. V. Satyanarayana, G. Malakondaiah, and D. S. Sarma, "Steady state creep behaviour of NiAl hardened austenitic steel," Materials Science and Engineering A, vol. 323, no. 1-2, pp. 119128, 2002.

[17] P.-Q. La, Y.-F. Li, S.-G. Liu, D. Shen, and H.-D. Wang, "Effect of aluminum on microstructure and mechanical properties of 316L steel," Iron and Steel, vol. 45, no. 5, pp. 71-75, 2010.

[18] L. Peiqing, L. Yufeng, and L. Shanguang, "Corrosion resistance of 316L stainless steel with Al," Materials Protection, vol. 43, no. 12, pp. 62-64, 2010.

[19] L. Peiqing and L. Shanguang, "Effect of aluminum on microstructure and mechanical properties of 310 S steel," Materials Engineerings, pp. 30-40, 2009.

[20] P.-Q. La, Y.-F. Li, and S.-G. Liu, "Effect of aluminum on high temperature oxidation resistance of $310 \mathrm{~S}$ steels," Iron and Steel, vol. 46, no. 1, pp. 66-69, 2011.

[21] Y. Yamamoto, M. L. Santella, M. P. Brady, H. Bei, and P. J. Maziasz, "Effect of alloying additions on phase equilibria and creep resistance of alumina-forming austenitic stainless steels," Metallurgical and Materials Transactions A, vol. 40, no. 8, pp. 1868-1880, 2009.

[22] L. Jing and H. Y. Hua, High Nitrogen Steels and Stainless Steels Manufacturing, Properties and Applications, Chemical Industry Press, Beijing, China, 2006.

[23] J.-E. Jin and Y.-K. Lee, "Effects of $\mathrm{Al}$ on microstructure and tensile properties of C-bearing high Mn TWIP steel," Acta Materialia, vol. 60, no. 4, pp. 1680-1688, 2012.

[24] J. Wang, P. J. Uggowitzer, R. Magdowski, and M. O. Speidel, "Nickel-free duplex stainless steels," Scripta Materialia, vol. 40, no. 1, pp. 123-129, 1998.

[25] A. N. Shuaib, "Mechanical properties of Al-2.5 Mg-0.1 Mn-SiCr-Fe alloys," Materials and Design, vol. 23, no. 2, pp. 181-187, 2002.

[26] X. B. Wang, The Physics of Materials Processing, Tianjin University Press, Tianjin, China, 2011.

[27] H. Hänninen, J. Romu, R. Ilola, J. Tervo, and A. Laitinen, "Effects of processing and manufacturing of high nitrogencontaining stainless steels on their mechanical, corrosion and wear properties," Journal of Materials Processing Technology, vol. 117, no. 3, pp. 424-430, 2001.

[28] J. R. Davis, “Corrosion behavior," in Stainless Steel: An ASM Specialty Handbook, ASM International, Materials Park, Ohio, USA, 1996.

[29] M. P. Brady, Y. Yamamoto, L. Zhaoping et al., "Aluminaformin austenitics: a new class of heat-resistant stainless steels," Stainless Steel World, vol. 3, pp. 23-29, 2008.

[30] R. Chaves, I. Costa, H. G. Melo, and S. Wolynec, "Evaluation of selective corrosion in UNS S31803 duplex stainless steel with electrochemical impedance spectroscopy," Electrochimica Acta, vol. 51, no. 8-9, pp. 1842-1846, 2006. 

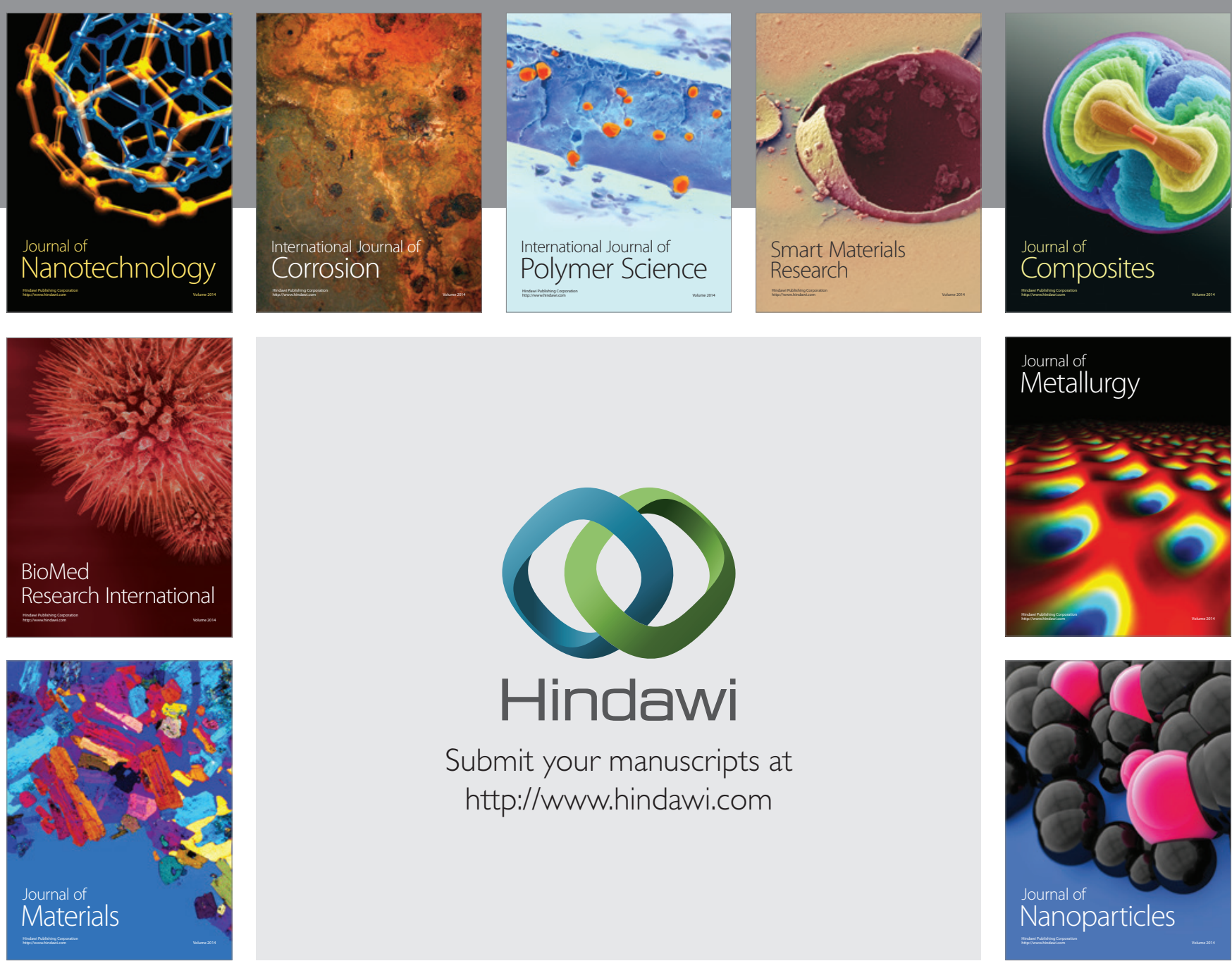

\section{Hindawi}

Submit your manuscripts at

http://www.hindawi.com

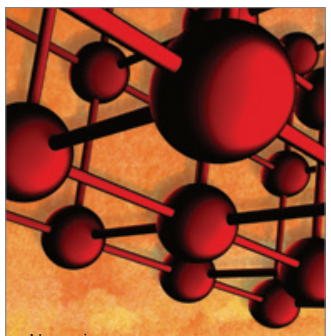

Materials Science and Engineering
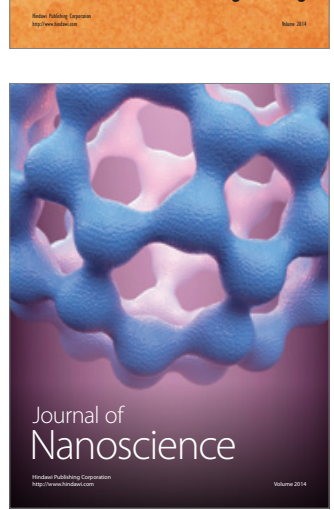
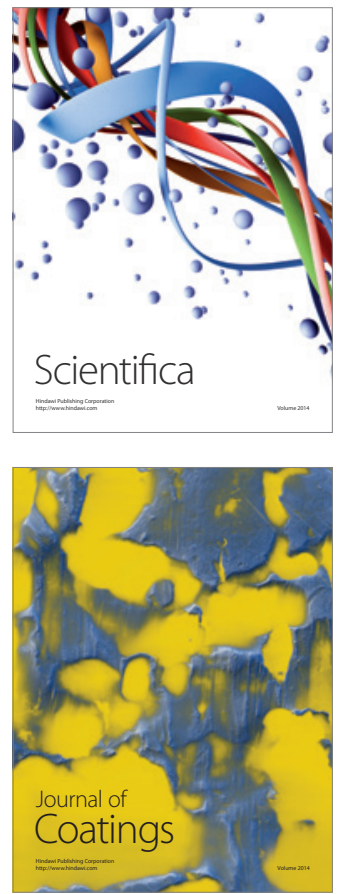
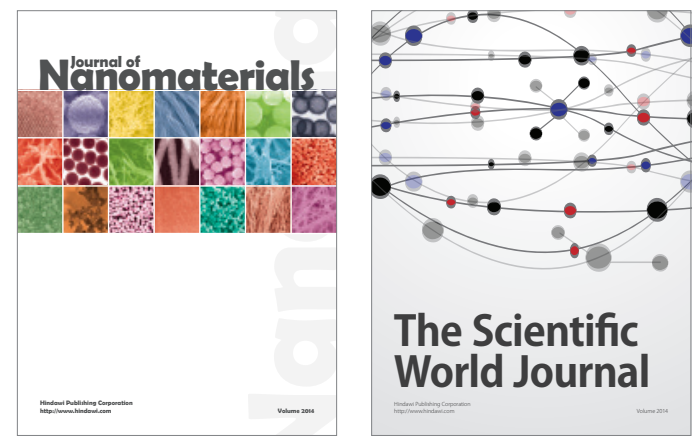

The Scientific World Journal
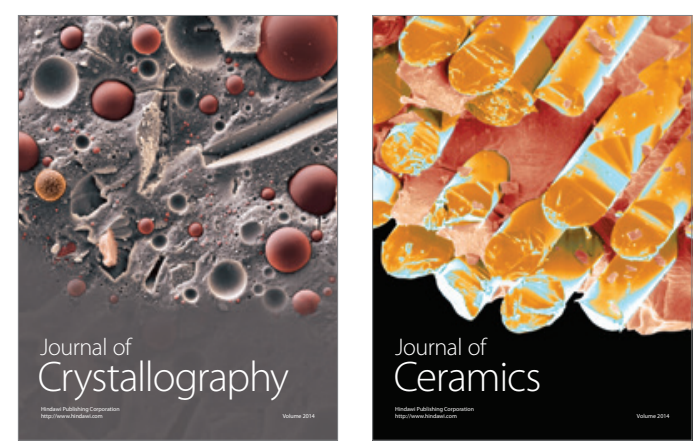
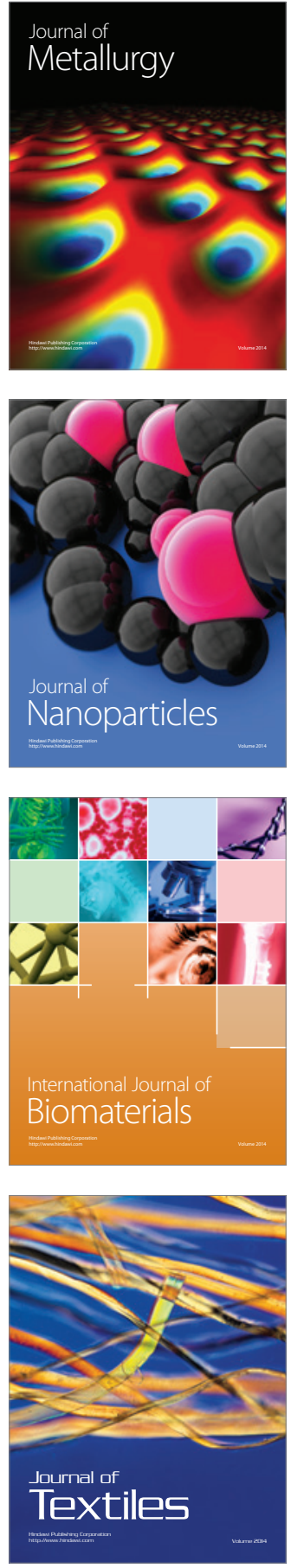